\title{
Demographic Factors Affecting Freshman Students' Attitudes towards Software Piracy: An Empirical Study
}

\author{
Ali Acılar \\ Bilecik University, Bilecik, Turkey \\ ali.acilar@bilecik.edu.tr
}

\begin{abstract}
The widespread use of computers and the Internet has provided many advantages to everyday life, but also created new opportunities for unethical and illegal acts such as software piracy. The Business Software Alliance (BSA) and International Data Corporation (IDC) estimated that worldwide software piracy rate went up to 41 percent in 2008 and worldwide losses to software vendors due to software piracy totaled more than $\$ 50$ billion in 2008 (BSA and IDC, 2009). Besides being an economic problem, software piracy is also an ethical issue, especially in academic settings. The evidences from numerous studies suggest that many undergraduate students consider software piracy and other unethical use of information technologies as an acceptable behavior.

The main purpose of the present study is to investigate the relationships between the demographic characteristics of freshman students and their attitudes towards software piracy. Data were obtained from a survey sample of 125 students in the Department of Business Administration at a public university in Turkey. The study found that overall attitudes of freshman students towards software piracy are close to neutral position on the Likert scale. The results of the regression analysis showed that monthly family income and duration of Internet usage in a week affected attitudes of freshman students towards software piracy, but to a lower extent.
\end{abstract}

Keywords: software piracy, softlifting, demographic factors, freshman students

\section{Introduction}

According to BSA, "Software piracy is the unauthorized copying or distribution of copyrighted software." Softlifting is accepted as the most common type of software piracy. It refers to illegal copying and sharing of legally licensed software (Rahim, Seyal, \& Rahman, 2001; Simpson, Banerjee, \& Simpson, 1994). The Sixth Annual BSA and IDC Global Software Piracy Study examined PC software piracy rates across 110 countries and reported that $41 \%$ of software in-

Material published as part of this publication, either on-line or in print, is copyrighted by the Informing Science Institute. Permission to make digital or paper copy of part or all of these works for personal or classroom use is granted without fee provided that the copies are not made or distributed for profit or commercial advantage AND that copies 1) bear this notice in full and 2) give the full citation on the first page. It is permissible to abstract these works so long as credit is given. To copy in all other cases or to republish or to post on a server or to redistribute to lists requires specific permission and payment of a fee. Contact 0HPublisher@InformingScience.org to request redistribution permission. stalled on computers worldwide was pirated in 2008, with estimated losses at $\$ 53$ billion (BSA and IDC, 2009). According to this report, piracy rate was 64 percent in Turkey, and that caused $\$ 468$ million loss in 2008. Software piracy problem is worldwide phenomenon. Software piracy occurs not only in developing countries, but also in developed countries (Law \& Wong, 2005). For example, piracy rates of Canada and 
France in 2008 were reported as $32 \%$ and $41 \%$, respectively. Even though the United States had the lowest piracy rate ( $20 \%$ in 2008), worldwide software piracy caused losses of $\$ 9,143$ million to the United States in 2008 (BSA and IDC, 2009).

As the use of computers and the Internet has increased dramatically, so has the illegal and unethical usage of these technologies. Even though Internet has become an essential tool for education and entertainment in the life of students, it is widely accepted that the spread of the Internet has facilitated growth of a variety of crimes, such as digital piracy (Gan \& Koh, 2006; Hinduja, 2001; Holt \& Morris, 2009; Van der Byl \& Van Belle, 2008). The advances in computer technology and the Internet have made it possible for people to access, store, change, and transmit the information much easier and faster than it used to be. However, these advantages have made also unethical behaviors much easier, particularly among students in academic settings (Abdul Karim, Zamzuri, \& Nor, 2009).

Software piracy has become an important problem for businesses and educational institutions (Hinduja, 2001), and continues as a variety of legal, economical and ethical issues. Studies show that software piracy in higher educational institutions is common and students perceive the use of unlicensed software as an acceptable behavior (Christensen \& Eining, 1991; Cohen \& Cornwell, 1989; Konstantakis, Palaigeorgiou, G., Siozos, P. \& Tsoukalas, 2005; Law \& Wong, 2005; Rawlinson \& Lupton, 2007; Siegfried, 2004; Siegfried \& Ashley, 2006).

\section{Literature Review}

There has been an increasing amount of literature about software piracy and other unethical uses of information technologies in the educational institutions. A considerable amount of these studies have investigated the relationship between software piracy and undergraduate students.

The results from previous studies suggest that most university students do not view software piracy as an unethical practice. Konstantakis et al. (2005) surveyed 79 freshman students of a Computer Science Department and found that all students illegitimately use or copy software that is protected by intellectual property rights. Cohen and Cornwell (1989) found from the results of the survey study of 309 students that $58 \%$ of the students had personally pirated. Cohen and Cornwell (1989) reported that an overwhelming majority of students feel that software piracy is an acceptable behavior and also many students feel that it is okay for them to pirate software. Christensen and Eining (1991) investigated unethical copying of software among accounting students in the United States and found that of the 139 students who owned computers, seventy-three percent reported engaging in software piracy and students' knowledge of the laws appeared to have little impact on piracy behavior. They also found that individuals do not perceive software piracy as an inappropriate behavior and that they do not believe that their friends and superiors think it is inappropriate. Law and Wong (2005) found that students don't accept buying pirated software as a shameful action. Siegfried (2004) studied 224 students and found that students generally felt that copying commercial software and downloading music from the Internet was acceptable. Siegfried and Ashley (2006) surveyed 190 college freshmen students and found that a majority of the respondents thought it was okay to copy software. It seems evident that software piracy in the universities is common and that students perceive the use of unlicensed software as an acceptable behavior (Rawlinson \& Lupton, 2007).

Age is one of the most studied demographic factors in relation to software piracy among students. Previous studies investigating the effects of age on the software piracy have produced conflicting results. Sims, Cheng, and Teegen (1996) surveyed 340 undergraduate business students and MBA students, and found that older students pirate software more frequently than younger students. Based on the data gathered from surveys of 226 distance computing students, Van Der Merwe (2006) found that younger distance computing students softlift more than older distance comput- 
ing students. Moores and Chang (2006) studied 243 students and found significant differences in the ethical decision making in software piracy process based on age. Results of a study conducted by Peslak (2007) showed that older individuals more readily follow ethical norms regarding copying others' software. Gan and Koh (2006) found age is negatively related to software piracy. Van der Byl and Van Belle (2008) surveyed 88 students and working individuals to investigate the factors influencing South African attitudes toward digital piracy. They found that students are more likely to digitally pirate than business professionals and age is negatively correlated with individuals' attitudes toward digital piracy. However, Hinduja (2003) didn't find significant differences between older and younger students in pirating behavior.

Gender is another important demographic factor that has received attention in the studies about software piracy. Sims et al. (1996) found that male students pirate software more frequently than female students. Lau (2003) found that male computer users were more lenient in their attitudes to pirated software than female users. Van Der Merwe (2006) found that male distance computing students are more likely to softlift than female distance computing students. Based on the results of surveying of 224 students, faculty, and professionals, Peslak (2007) found that females had a higher recognition of copying others' software than males. Even though the majority of the studies found that male students are more likely to pirate software than female students, some studies didn't find the same result. For example, Moores and Chang (2006) found that male and female students interpret the act of software piracy similarly. Van der Byl and Van Belle (2008) didn't find statistically significant relationship between gender and digital piracy.

Since software piracy is also an ethical issue, some researchers investigated the relationship between software piracy and variables such as moral values, religiosity and culture. Based on the results of the sample of 363 undergraduate students Logsdon, Thompson, and Reid (1994) investigated the relationship between level of moral judgment and attitudes toward software copying and didn't find a significant relationship. Simpson et al. (1994) studied 209 students in the United States and found religion as a potential influencer in the propensity to pirate software. Based on the data from the survey of 167 undergraduate students Wagner and Sanders (2001) found that individuals with conservative religious beliefs (high religion) will be less likely to evaluate an unethical act such as software piracy as being fair, just, morally right and acceptable (high moral equity). Siegfried (2004) studied 224 students and found that there was no significant correlation between student attitudes and their school's religious affiliation. Woolley and Eining (2006) surveyed 481 accounting students in the United States and found that attitudes of students and their subjective norms toward software piracy directly related to software piracy behavior. Van der Byl and Van Belle (2008) found that Machiavellianism, cognitive beliefs and positive affective beliefs show significant correlation to an individual's attitude toward digital piracy.

It is expected that students with lower family income are more likely to pirate software, since they cannot afford the original software (Liang \& Yan, 2005). Rahim et al. (2001) investigated factors affecting softlifting intention of computing students using survey data collected from 205 students and they found that family income affect softlifting intention of students, but to a lesser extent. Lau (2003) was found that household monthly income of the computer users was not associated with their reported leniency towards software piracy.

PC experience is another studied factor affecting software piracy. It is expected that computer experienced students may opt for pirated software (Rahim et al., 2001). Sims et al. (1996) found that students who tended to use computers more are more likely to pirate software. Rahim et al. (2001) found no significant relationship between PC ownership, PC experience and softlifting intention. Van Der Merwe (2006) found that the more personal computer experience distance computing students have, the more likely they are to softlift. Cronan, Foltz, and Jones (2006) found that students having greater familiarity with computers report committing greater amounts of misuse of information systems. Hinduja (2003) found that students who are highly skilled at 
Internet-related activities are more likely to be software pirates than students who demonstrate a lower skill level.

\section{Research Methodology}

A self-report questionnaire was used as a data collection instrument for this study. Eleven statements (listed in Table 2), developed by Rahim et al. (2001), were used to measure students' attitudes towards software piracy. Statements were measured on a five-point Likert-type scale ranging from strongly disagree (1) to strongly agree (5). As a measure of internal consistency, Cronbach's alpha was calculated for the 11 items. The resultant alpha coefficient of 0.883 provided evidence of adequate internal consistency. Demographic variables included in the study were gender, age, monthly family income, PC ownership, computer experience, duration of computer and the Internet usage in a week, computer knowledge and religiosity. Single item measures were used for independent variables. To measure religiosity, students were asked to rate their religiosity via a Likert scale ranging from not religious to very religious.

The data for this study was obtained by surveying a sample of one hundred and sixty freshman students at the Department of Business Administration at a public university in Turkey. The survey was conducted in November 2009. After eliminating incomplete and unusable responses, 125 usable responses were used for analysis. 52.8 percent of the participants were male. Most of the participants $(74.4 \%)$ were 18 or 19 years old. 64 students $(51.2 \%)$ reported that their monthly family income was less than 1000 Turkish liras.

65.6 percent of the participants owned a personal computer (PC). Most of the students $(69.6 \%)$ reported 6 years or less of PC experience. $60.8 \%$ of the respondents reported that they use the Internet eight hours or less in a week. Minority of the respondents (16.8\%) reported their computer knowledge level as very poor or poor. 42.4 of the respondents rated their religiosity as average, 39.2 of them rated as religious, and 5.6 of them rated as very religious. The demographic characteristics of the participants are presented in Table 1.

Table 1: The Demographic Characteristics of the Participants

\begin{tabular}{|c|c|c|}
\hline & Frequency & $\%$ \\
\hline $\begin{array}{l}\text { Gender } \\
\text { Male } \\
\text { Female }\end{array}$ & $\begin{array}{l}66 \\
59\end{array}$ & $\begin{array}{l}52.8 \\
47.2\end{array}$ \\
\hline $\begin{array}{l}\text { Age } \\
18-19 \\
20-24\end{array}$ & $\begin{array}{l}93 \\
32\end{array}$ & $\begin{array}{l}74.4 \\
25.6\end{array}$ \\
\hline $\begin{array}{l}\text { PC Ownership } \\
\text { Yes } \\
\text { No }\end{array}$ & $\begin{array}{l}82 \\
43 \\
\end{array}$ & $\begin{array}{l}65.6 \\
34.4 \\
\end{array}$ \\
\hline $\begin{array}{l}\text { Computer Experience } \\
\leq 6 \text { years } \\
\geq 7 \text { years }\end{array}$ & $\begin{array}{l}87 \\
38\end{array}$ & $\begin{array}{l}69.6 \\
30.4\end{array}$ \\
\hline $\begin{array}{l}\text { Duration of Internet Usage in a Week } \\
\leq 8 \text { hours } \\
\geq 9 \text { hours }\end{array}$ & $\begin{array}{l}76 \\
49 \\
\end{array}$ & $\begin{array}{l}60.8 \\
39.2\end{array}$ \\
\hline
\end{tabular}

\section{Results}

The objective of the analysis was to investigate the relationships between demographic factors and attitudes of freshman students towards software piracy. A mean score for each attitude item 
was computed and presented in Table 2. The mean score of six items above the neutral position on the Likert scale. Among the eleven items, the highest mean score is 3.46 (I see nothing wrong in using pirated software if it is badly needed for the success of a project.) and the lowest mean score is 2.33 (I think it is okay to use pirated software to improve my productivity.).

Overall mean for the eleven attitude items for participants was calculated as 2.94 , which is very close to the neutral position on the Likert scale. It suggests that the majority of the participants do not have a strong opinion about software piracy either way.

Table 2: Mean Scores of Attitude Items

\begin{tabular}{|l|c|c|}
\hline Attitude Items & Mean & $\begin{array}{c}\text { Standard } \\
\text { Deviation }\end{array}$ \\
\hline $\begin{array}{l}\text { I think it is not okay to use pirated software because it may create negative im- } \\
\text { age.* }\end{array}$ & 2.54 & 1.27 \\
\hline I think pirated software helps monetary savings. & 3.35 & 1.32 \\
\hline I think it is okay to use pirated software to improve my productivity. & 2.33 & 1.12 \\
\hline $\begin{array}{l}\text { I see nothing wrong in giving friends copies of my software in order to foster } \\
\text { friendship. }\end{array}$ & 2.86 & 1.25 \\
\hline I think it is okay to use pirated software if it improves my knowledge. & 3.31 & 1.23 \\
\hline $\begin{array}{l}\text { I think it is okay to use pirated software because community at large is eventually } \\
\text { benefitted. }\end{array}$ & 2.77 & 1.16 \\
\hline I believe that software piracy helps to increase my computer literacy. & 2.54 & 1.13 \\
\hline I think it is okay to use pirated games software for entertainment. & 2.78 & 1.25 \\
\hline $\begin{array}{l}\text { I see nothing wrong in using pirated software if it is badly needed for the success } \\
\text { of a project. }\end{array}$ & 3.46 & 1.26 \\
\hline $\begin{array}{l}\text { I think it is okay to use pirated software for research purpose, because everybody } \\
\text { shares the benefits. }\end{array}$ & 3.13 & 1.19 \\
\hline $\begin{array}{l}\text { I think software piracy is okay to punish software publishers who charge very } \\
\text { high price. }\end{array}$ & 3.34 & 1.19 \\
\hline
\end{tabular}

*Reverse coded

Regression analysis was used to explore the relationships between the demographic characteristics of the participants and their attitudes towards software piracy, measured by an 11-item Likert scale. Nine demographic characteristics were investigated as potential variables affecting attitudes of students towards software piracy. They were gender, age, monthly family income, PC ownership, computer experience, duration of Internet usage in a week, duration of computer usage in a week (excluding Internet usage), computer knowledge level, and religiosity. The results of stepwise regression analysis are presented in Table 3.

Table 3: The Results of Stepwise Regression Analysis

\begin{tabular}{|l|c|c|c|c|}
\hline & B & Beta & t & $\boldsymbol{p}$ value \\
\hline Monthly Family Income & 0.220 & 0.231 & 2.667 & 0.009 \\
Duration of Internet Usage in a Week & 0.064 & 0.183 & 2.109 & 0.037 \\
\hline $\mathrm{R}^{2}=0.098, \quad \mathrm{~F}=6.594, \quad p=0.002$
\end{tabular}

The results of the stepwise regression analysis suggest that monthly family income and duration of Internet usage in a week affected attitudes of freshman students towards software piracy, but to 
a lower extent. It was found that there is a positive relationship between monthly family income and software piracy attitude. This result is interesting, since it was expected that lower-familyincome students were more likely to pirate software.

A significant relationship was not found between attitudes of freshman students towards software piracy and other demographic variables that were gender, age, PC ownership, computer experience, duration of computer usage in a week (excluding Internet usage), computer knowledge level, and religiosity.

\section{Conclusions}

Software piracy is one of the most common types of computer crimes, especially in higher educational institutions. The main aim of the present study, which is part of ongoing research, was to explore the relationships between demographic characteristics of freshman students and their attitudes towards software piracy.

Based on the results obtained from this study, it is concluded that overall attitudes of freshman students towards software piracy are close to neutral position on the Likert scale. The majority of the participants do not have a strong opinion about software piracy either way.

The results of the stepwise regression analysis show that attitudes of freshman students towards software piracy were affected by monthly family income and duration of Internet usage in a week, but to a lower extent. Unexpectedly, it was found that there is a positive relationship between monthly family income and software piracy attitude.

Although the majority of the studies reported that gender and age affect students' attitudes towards software piracy, this study didn't find a significant relationship between gender, age, and freshman students' attitudes towards software piracy. Results of the present study also indicate that PC ownership, computer experience, duration of computer usage in a week (excluding Internet usage), computer knowledge level, and religiosity do not significantly affect freshman students' attitudes towards software piracy.

In order to minimize software piracy among university students, proactive steps should be taken. Education is one of the most common recommendations in the literature for preventing software piracy and raising awareness of software piracy among students. Education on ethical topics and information technology use should include ethical use of information technologies and software in the curriculum and should be supported by the real case studies. Giving examples of arrested software pirates in the lectures might create a deeper awareness of the seriousness of the consequences of software piracy.

A clearly stated information technology usage policy should be adopted by the universities. And, students should be informed about relevant legislation and university policy for use of information technology resources.

There are also technological measures that can be used by the universities for preventing software piracy in the campus. Internet traffics should be monitored in the university. Filtering out certain types of data, illegal Internet traffics and piracy websites may help to reduce software piracy among students (Hinduja, 2003).

A number of limitations need to be considered in this study. First, the convenience sampling technique was used for the selection of the sample. Second, the survey was conducted among students in the Department of Business Administration in a public university in Turkey. Also, the low value of $\mathrm{R}^{2}$ indicates that the model needs to be improved. 


\section{References}

Abdul Karim, N. S., Zamzuri, N. H. A., \& Nor, Y. M. (2009). Exploring the relationship between Internet ethics in university students and the big five model of personality. Computers \& Education, 53(1), 8693.

Business Software Alliance (BSA). (2009). Retrieved November 11, 2009 from http://www.bsa.org

BSA \& IDC. (2009). The Sixth annual BSA-IDC global software piracy study. Retrieved October 20, 2009 from http://global.bsa.org/globalpiracy2008/studies/globalpiracy2008.pdf

Christensen, A. L., \& Eining, M. M. (1991). Factors influencing software piracy: Implications for accountants. Journal of Information Systems, 5, 1, 67-80.

Cohen, E. \& Cornwell, L. (1989). College students believe piracy is acceptable. CIS Educator Forum, 1(3), 2-5.

Cronan, T. P., Foltz, C. B., \& Jones, T. W. (2006). Piracy, computer crime, and IS misuse at the university. Communications of the ACM, 49(6), 85-90.

Gan, L. L., \& Koh, H. C. (2006). An empirical study of software piracy among tertiary institutions in Singapore. Information \& Management, 43, 640-649.

Hinduja, S. (2001). Correlates of internet software piracy. Journal of Contemporary Criminal Justice, $17(4), 369-382$.

Hinduja, S. (2003). Trends and patterns among software pirates. Ethics and Information Technology, 5 (1), 49-61.

Holt, T. J., \& Morris, R. G. (2009). An exploration of the relationship between MP3 player ownership and digital piracy. Criminal Justice Studies, 22(4), 381-392.

Konstantakis, N., Palaigeorgiou, G., Siozos, P., \& Tsoukalas, A. I. (2005). An empirical study of freshmen attitudes towards privacy and software piracy and their instructional implications. Proceedings of IADIS International Conference e-Society 2005, 386-394.

Lau, E. K. W. (2003). An empirical study of software piracy. Business Ethics: A European Review, 12(3), 233-245.

Law, R., \& Wong, D. (2005). How do hospitality and tourism students view software piracy? Asia Pacific Journal of Tourism Research, 10(3), 263-273.

Liang, Z., \& Yan, Z. (2005). Software piracy among college students: A comprehensive review of contributing factors, underlying processes, and tackling strategies. Journal of Educational Computing Research, 33(2), 115-140.

Logsdon, J. M., Thompson, J. K., \& Reid, R. A. (1994). Software piracy: Is it related to level of moral judgment? Joumal of Business Ethics, 13, 849-857.

Moores, T. T., \& Chang, J. C. (2006). Ethical decision making in software piracy: Initial development and test of a four-component model. MIS Quarterly, 30(1), 167-180.

Peslak, A. R. (2007). Information technology intellectual property ethics: Issues and analysis. Issues in Information Systems, 7(2), 207-213.

Rahim, M. D. M., Seyal, A. H., \& Rahman, M. N. A. (2001). Factors affecting softlifting intention of computing students: An empirical study. Journal of Educational Computing Research, 24(4), 385-405.

Rawlinson, D. R., \& Lupton, R. A. (2007). Cross-national attitudes and perceptions concerning software piracy: A comparative study of students from the United States and China. Journal of Education for Business, 83(2), 87-94.

Siegfried, R. M. (2004). Student attitudes on software piracy and related issues of computer ethics. Ethics and Information Technology, 6, 215-222. 
Siegfried, R. M., \& Ashley, A. S. (2006). Is it theft or sampling- Student attitudes on the copying of commercial software and music. Proceedings of the Information Systems Education Conference 2006, v.23 (Dallas): $\$ 3334$.

Simpson, P. M., Banerjee, D. \& Simpson, C. L. (1994). Softlifting: Model of motivating factors. Journal of Business Ethics, 13, 431-438.

Sims, R. R., Cheng, H. K., \& Teegen, H. (1996). Toward a profile of student software piraters. Journal of Business Ethics, 15(8), 839-849.

Van der Byl, K., \& Van Belle, J. P. (2008). Factors influencing South African attitudes toward digital piracy. Communications of the IBIMA, 1(1), 202-211.

Van Der Merwe, T. M. (2006). A profile of the distance computing student softlifter. Proceedings of Information Security South Africa (ISSA) Conference, 1-20.

Wagner, S. C., \& Sanders, G. L. (2001). Considerations in ethical decision-making and software piracy. Journal of Business Ethics, 29, 161-167.

Woolley, D. J., \& Eining, M. M. (2006). Software piracy among accounting students: A longitudinal comparison of changes and sensitivity. Journal of Information Systems, 20(1), 49-63.

\section{Biography}

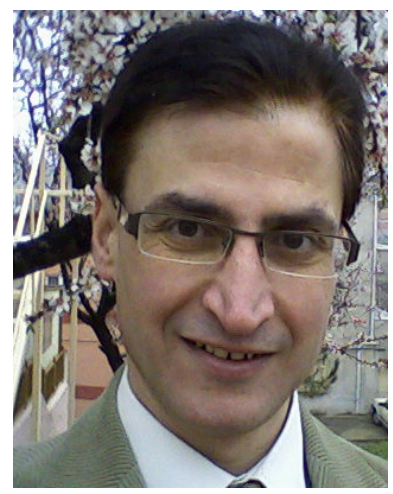

Ali Aclar is an assistant professor in the Department of Business Administration, Bilecik University, Bilecik, Turkey. He graduated from the Department of Business Administration at Hacettepe University, Ankara, Turkey, received his MS in Operation Research and Statistics from Rensselaer Polytechnic Institute (RPI), Troy, NY, USA and obtained his Ph.D in Business Administration from Dumlupinar University, Kütahya, Turkey in 2007. His research interest includes information technology usage in SMEs, ethical use of information technology, gender issues in computer ethics, e-commerce and e-government. 